\title{
The Impact of Using Analytical Procedures on Reducing the Cost of Tax Audit \\ "The Jordanian Income and Sales Tax Department"
}

\author{
Israa Mansour $^{1}$, Mutasem Kalib ${ }^{2}$ \\ ${ }^{1}$ Faculty of Business, Applied Science Private University, Amman, Jordan \\ ${ }^{2}$ Tax Auditor, JCPA, Income and Sales Tax Department, Amman, Jordan \\ Correspondence: Israa Mansour, Faculty of Business, Applied Science Private University, Amman, Jordan.
}

Received: December 17, 2018

Accepted: January 8, 2019

Online Published: January 17, 2019

doi:10.5539/ibr.v12n2p52

URL: https://doi.org/10.5539/ibr.v12n2p52

\begin{abstract}
The study aimed to exam the impact of using the analytical procedures on reducing the cost of a tax audit in the Jordanian Income and Sales Tax Department. To achieve the aim of the study, the analytical descriptive approach has been used and a questionnaire has been designed and given out to the study sample, which represented from the auditors of Directorate of senior taxpayers and directorates of medial taxpayers in the income tax department and sales who work in these directorates. The appropriate statistical methods have been used to find results.

The findings showed that using the analytical procedures led to reducing the cost of a tax audit in all auditing stages. The stage, which has the most impact of using the analytical procedures on reducing the cost, is the final auditing stage followed by the planning stage and the implementation (fieldwork) stage.

The study recommended the necessity of compulsion of the auditors in tax department to use the analytical procedures because it reduces the cost of tax auditing and the necessity of holding workshops and training programs to define the importance of analytical procedures in tax auditing.
\end{abstract}

Keywords: analytical procedures, auditing stages, cost of tax audit

\section{Introduction}

International Standards on Auditing (ISA) represent the rules, procedures, and guidelines that auditors are required to abide by with the aim of attaining the best results in order to give the impartial technical opinion about the fairness of the financial statements and how they validly represent the results. The tax audit is a complex procedural process which consists of several chronological stages; administration's confirmations in documenting and verifying the financial statements during the accounting period is an introduction to the financial reporting, which is a result of the presentation of the tax returns. Therefore, the tax audit aims to verify the fairness of the financial statements submitted within the tax returns using the tax audit methods derived from the Generally Accepted Auditing Standards (GAAS), as well as other rules and standards. In other words, the tax audit and the financial audit, with its internal and external types, are based on legal or professional rules issued by accredited legal or professional enterprises to judge the fairness of the financial statements presented from individuals or companies to the required entities. Therefore, the object of the tax audit does not differ very much from the object of the financial audit; which is to express the impartial and the technical opinion about the fairness of the financial statements. However, the difference between them arises in the application of rules and standards. The financial audit science is subjected to the Generally Accepted Auditing Standards (GAAS), while the tax audit uses these standards in addition to the legal requirements of tax laws (Olaoye, 2018). The analytical auditing procedures are used in several stages during the auditing; these stages are as follows: the planning stage, the initial auditing process, the fieldwork stage (implementation of the auditing process), and the completion of the auditing process stage (Arens et al, 2015). Each of the tax auditing stages includes auditing costs such as fees of the chief auditor's assistant team, so tax auditor seek to the methods and techniques that attempt reduce this cost, analytical procedures are one from techniques.

This study is concerned with measuring the impact of using the analytical procedures on reducing the cost of a tax audit. Jordan is considered one of the countries that applied International Standards on Auditing (ISA) 
because of the absence of national professional standards that govern the auditing profession in general and tax audit in particular. The tax audit is of paramount importance in increasing public revenues (Lushi, 2016). A number of factors, which the researchers believe that they reflect the impact of using the analytical procedures on reducing the cost of the tax audit, were selected. Since the tax provides $60 \%$ of the annual revenues of the state budget, it is necessary to look for the best methods and procedures that ensure the formation of the fairest tax returns and the prevention of fraud and manipulation by taxpayers, at the lowest cost possible. This is what we mean by the efficiency of the auditing process, which has its own implications and reflections on the increase of tax revenues for the state. The results of this study will contribute to the development of the analytical procedures used in all stages of the tax audit, which will enhance the efficiency of the auditing process and will be used by the auditors in the income and sales tax department, especially with the scarcity of studies that have addressed the impact of the analytical procedures on reducing the cost of the tax audit.

\subsection{Objectives of the Study}

The application of the analytical procedures may give a clear indication of the efficiency of the service provided by the tax auditor to customers in order to ensure the continuity of enterprises as part of the economic construction of the society and thus its reflection on the quality of the tax audit to maintain the public revenues of the state and the rights of shareholders especially that tax, as mentioned earlier, contributes significantly to the state revenues. The auditing requires costs to be spent at all stages of the tax audit. Therefore, the study aims to identify the impact of using the analytical procedures during the all stages of the tax audit on reducing the cost of the tax audit, also in each auditing stage the tax audit.

\subsection{Problem and Important of the Study}

The analytical procedures are crucial to ascertain the opinions of economists and their expectations regarding the growth of different companies or sectors where the audited enterprise is considered one of its key components. Hence, the importance of the analytical procedures emerges in the sense that any abnormalities or abnormal growth in the activity of the audited enterprise can be detected. The importance of the analytical procedures is obvious in terms of the ability of the auditor to judge the possibility of continuity of the enterprise or not (Pinho, 2014). The importance of studying the impact of using the analytical procedures on reducing the cost of the tax audit also appears in presenting a proposed approach to develop the practice and performance of the tax audit through the use of the analytical procedures, as well as focusing on the importance of the analytical procedures by judging fraud, deception or tax evasion in the financial statements, which substantially reflect the impact on the cost of the tax audit.

Because the analytical procedures provide a necessary tool for aspects and elements, where auditing risks may be high; hence, auditors in general and tax auditors, in particular, should pay more professional attention to assess all financial and non-financial information, all stages of auditing at the lowest cost, taking into consideration the reasonableness of the cost. Thus, the study problem can be identified in the vagueness of the impact of using the analytical procedures in auditing on the cost of the tax audit and the reflection of that on the efficiency of the auditing process at the Income and Sales Tax Department in Jordan.

Based on the above, the study problem can be summed up as follows: "What is the impact of using the analytical procedures during all stages of auditing on reducing the cost of a tax audit in Jordan?"

The next parts of the research will review the importance of the analytical procedures and methods in the tax audit stages of this study by reviewing the most important studies in this field. This is to be followed by the research methodology along with the presentation of results, conclusions, and recommendations.

\subsection{Analytical Procedures}

\subsubsection{Analytical Procedures Concept}

The International Federation of Accountants (IFAC) defined the analytical procedures through (ISA.NO.520) as: "evaluations of financial information through analysis of plausible relationships among both financial and non-financial data. Analytical procedures also encompass such investigation as is necessary of identified fluctuations or relationships that are inconsistent with other relevant information or that differ from expected values by a significant amount. (www.IFAC.org). Thus, the analytical procedures are the executive steps used by the auditor when performing the auditing process. Therefore, the application of the analytical procedures by the auditor achieves credibility, because these procedures allow the auditor to make the comparisons for balances and the financial and the non-financial data to identify the differences or changes in those balances and data and then identify the evidence through which the auditor can determine the reasons for such changes and may, therefore, detect errors, fraud or new activities by the enterprise under audit (Bednarek,2016; Al-Sharairi, 
2011). Therefore, the analytical procedures are the most important evidence to be used by the auditor in the auditing process to identify the enterprise's specific indicators through which he can identify its weaknesses and strengths. Therefore, the availability of the analytical procedures for auditor serves as evidence of the validity of results and the recorded financial values. In the search for the significant changes in these results, the auditor needs to gather sufficient evidence to substantiate his or her opinion in his report, which provides more opportunity to have evidence, presumptions and early detection of errors (Bednarek, 2016; Glover et al., 2015).

(Tandon, 2007; Soltani, 2007) pointed out that the nature of the analytical procedures is either to be a comparative study, where the auditor compares the actual data of the audited enterprise with information from different sources to identify the significant or fundamental changes that require research; which may include the study of the comparison results with other information such as a comparison with information from previous years. It could be also the study of relations; which is the analysis of relations through the study of the relationship between the elements of auditing with other elements (other components) to ensure that they match the expectations of auditing such as analysis of the relationship between the financial information to each other or the relationships between the financial information and the non-financial information (statistical).

\subsubsection{Importance of Analytical Procedures}

The importance of analytical procedures emerges from the risks that the auditors encounter which emerge from accepting financial statements as fair, while they contain distortions, or reject financial statements that are in fact fair and represent the financial position. This is what is called the overall risk (Rittenberg et al., 2010). The inherent causes of the audit risks may be associated with the application of ineffective audit procedures, either at the planning stage of the audit processor at the stage of its implementation. The importance of using analytical procedures is as follows (Knapp et al., 2001; Pinho, 2014):

1- Help reduce the time and effort required for the audit process.

2- Reduce the size of the audit sample and other audit tests.

3- Detect errors in the financial statements as well as errors in balances and deletions.

4- Discover unusual items and unexpected items.

5- Increase the effectiveness of auditing in general and predict some balances of the financial accounts and the enterprise's ability to continue.

The importance of the analytical procedures increases when the reliance on information increases, which is reflected in the results of the audit process. The analytical procedures are also more important in determining the fluctuations or relationships that are inconsistent with other relevant information obtained or deviating from the forecasted amounts. Therefore, the role of the auditor, in this case, is to audit, obtain adequate explanations, and establish the appropriate evidence. The effective analytical procedures ensure that the audit process is efficient as the auditor performs the audit process with the lowest cost and with the least effort possible (Messier et al., 2012).

\subsubsection{Methods of the Analytical Procedures}

According to International Standards on Auditing (ISA), the auditor can use many of the analytical procedures and relevant methods starting from simple comparisons and ending with complex analyses that use advanced statistical techniques ( Arens et al, 2015). Many ways can be followed to implement these procedures using monetary, quantitative, or relative measures through the enterprise's financial information, and these procedures have been classified into three main types. The first type is the descriptive analytical methods such as inquiry and the expectations from the results of the previous audit. The second type is the quantitative methods that rely on financial analysis (simplified quantitative methods); the most important of which are the analysis of financial ratios and horizontal and vertical analysis. The third type is an advanced statistical quantitative method, such as the analysis of regression, whether simple or multi-regression and analysis of time ranges.

The analytical procedures differ according to the types of data that the auditor compares. According to (Dittenhofer, 2001; Arens et al., 2014) analytical procedures fall under five types as follows:

First: Comparison of the audited entity's data with the data of the activity in which it operates, which contributes to providing useful information about the performance of the audited entity.

Second: Comparison of the audited entity's data with the corresponding data in the previous period. If the auditor noted an increase or decrease in one of these percentages and indicators, he must predict the reasons that might lead to that rise or fall according to his experience and then determine the evidence that he must collect to ascertain those possibilities. 
Third: Comparison of the audited entity's data with its expectations. It is often applied to the audit process of the government sector, where they prepare estimated budgets about accounting periods and then compare them with the actual data. The existence of differences between the estimated data and the actual data indicates changes that require the auditor to look for its reasons and be convinced with it.

Fourth: Comparison of the audited entity's data with the auditor's expectations. The auditor performs a calculation to attain the expected values of certain balances in the financial statements, which are based on some historical trends of those balances, compares the results of these analytical procedures with the audited entity's data, and then indicates the balances that are required to be checked and collect all its evidence.

Fifth: Comparison of the audited entity's data with the results using non-financial data. The auditor uses it to verify the balances of some accounts or to audit some balances.

\subsubsection{Steps of Using the Analytical Procedures}

The auditor can adopt the following four basic steps to make full advantage of the analytical procedures (Messier et al., 2013; Soltani., 2007; Knechel and Salterio, 2016):

Step 1: Forming expectations: The expectations represent the values in which the financial statements are expected to appear. The auditor develops his or her expectations in such a way that indicates the difference between the expected values and the actual recorded values in the books.

Step 2: Comparison between the expectations and the actual data: After determining expectations, the next step is to identify deviations of amounts or recorded values from expectations by comparing between expectations or predicted ratios by the auditor with the actual results, ratios, and indicators derived from the enterprise's financial statements and its records. One of this step's priorities is that the auditor should specify the rules of the decision in advance to determine what will be considered a fundamental difference, in other words, to determine whether the deviations represent unusual fluctuations.

Step 3: Exploring the causes of differences: The auditor should determine the causes of the changes or differences resulting from using the analytical procedures. These changes may be resulted from errors or infractions or may be due to economic circumstances and not due to errors or infractions. In order to clarify the causes for these changes, the auditor asks the customer's administration. It is important in a step that the auditor maintains his professional suspicion when submitting the answers he receives from the employees of the enterprise.

Step 4: Evaluating the expected impact of differences: The auditor evaluates the expected impact of such differences on the appropriateness and validity of the financial statements in the light of the administration's explanations. When the administration is unable to provide reasonable explanations for the causes that lead to such fundamental differences or modifications, the auditor must perform additional procedures to investigate these differences more.

\subsection{The Tax Audit}

The U.S. Government Accountability Office (GAO) defines the tax audit as "collecting and evaluating the evidence of information authorized under the tax statement submitted by the taxpayer to determine whether he has paid the correct tax amount" and as stated in (The Revised Audit Procedures Manual, 2015) "It is an activity or group of activities that attempt to determine the extent to which the taxpayer is properly committed by evaluating the taxpayer's compliance with applicable tax laws and verifying the accuracy and validity of the tax returns that have been submitted. Therefore, the auditor's main role is to determine whether taxes are properly declared by verifying the accuracy and completeness of the tax returns and their attachments". The tax audit is the process of determining the taxable income using tax accounting science, examining and analyzing the taxpayer's data and his activity and what the department has of data and ratifications from his/her customers, the connection between them and the issuance of a decision specifying the value of the tax. (Lushi, 2016; Murphy and Higgins, 2016).

\subsubsection{Objectives of the Tax Audit}

The importance of the tax audit lies in the fact that it is a mean and not an end. It aims to serve the tax administration in determining the tax base in an organized scientific way that preserves the rights of the taxpayers and the state side by side in addition to increasing the level of compulsion with the tax legislation and compliance with it, reducing cases of tax evasion and its forms, and increasing the tax revenue. These all support the tax system in achieving its financial, economic and social goals (Olaoye and Ogundipe, 2018; Oyedokun, 2016). According to (the Income and Sales Tax Department Guide, 2015) the effective audit program used in the 
Income and Sales Tax Department is Audit Management System (AMS) which uses the analytical procedures in a mandatory manner at all stages of the audit, aims to:

- Ensuring the compulsion of taxpayers with the applicable tax laws.

- Enhancing accuracy in filling out the tax returns by educating taxpayers about the proper application of tax laws and regulations.

- Encouraging voluntary compliance with taxpayers through the transparency of audit, this would reveal non-compliant individuals and expose them to sanctions.

- Gathering information on the integrity of the tax system as a whole by identifying tax compulsion issues.

\subsubsection{Reducing the Cost of Tax Audit}

The audit function at all stages includes different costs, including the fees of the chief auditor's assistant team, and the mobility costs of the audit team, especially if the audited company has branches. The use of auditing programs, detailed tests, and sample size increase the auditing costs. Seeking help from experts in a particular field of activity is among the costs of the auditing process. Therefore, the auditor attempts to apply the cost-benefit principle, which means achieving the most significant achievement from the auditing process with reasonable costs if it is compared to the desired benefit of the auditing process, and this costs vary from time to time depending on the time taken (Solayman, 2017; Al-Sharairi, 2011). On the other hand, the costs of implementing the analytical procedures may be expensive at all stages of the auditing (Dittenhofer, 2001). From the above, the main hypothesis can be formulated as follows:

H0: There is no statistically significant impact of using the analytical procedures during all stages of the auditing on reducing the cost of a tax audit in Jordan.

\subsubsection{Stages of the Auditing that the Analytical Procedures Used on It}

An auditor can apply the analytical procedures in three stages of the auditing process (Gendron et al., 2007; Dittenhofer, 2001; Mumford, 2017) which are:

Stage One: Using the analytical procedures at the planning stage of the auditing process. Planning is a vital step in the activity of the auditing process in the first stage. The auditor seeks to develop his or her expectations of possible deviations in the financial statements in order to develop an auditing strategy that is appropriate to the circumstances. Therefore, the auditing strategy relies on the auditor's expectations of possible errors or distortions in the financial statements. The use of the analytical procedures in the planning process enables the auditor to obtain some indicators that may indicate some gaps and deficiencies and thus prepare an auditing plan that is appropriate to the indicators obtained through the analytical procedures. This leads to a deep understanding of the financial position of the enterprise and its performance by analyzing the main financial indicators. The use of the analytical procedures during the planning of the auditing process helps the auditor to determine the nature of the auditing procedures used by him/her to obtain the necessary evidence for some accounts balances or a group of transactions (Montgomery et al., 2002; Ahmad, 2014) points out that the most stage where the analytical procedures are used at accounting divan is the planning stage. Based on the above, the first sub-hypothesis can be developed:

- H01: There is no statistically significant impact of applying the analytical procedures during the planning stage on the cost of a tax audit in Jordan.

Stage Two: Implementation (Fieldwork Auditing).At this stage, the auditor applies the analytical procedures during the auditing process or during the field auditing stage. The analytical procedures during this stage are more efficient and economical in terms of time-saving when compared with the detailed tests. The auditor, in carrying out the detailed tests or fundamental auditing, faces the risk of discovery; that is, fundamental distortion can occur without detection even after the auditing process is performed. The source of this risk may be due to the use of the inspection way in auditing which is divided into the risk of false rejection and the risk of false acceptance (Arens et al, 2015; Montgomery et al, 2002). Based on the above, the second sub-hypothesis can be formulated.

- $\mathrm{HO}_{1}$ : There is no statistically significant impact of using the analytical procedures during the implementation auditing stage on the reducing cost of a tax audit in Jordan.

Stage Three: Using the analytical procedures at the final of the auditing process.

The application of the analytical procedures in the final steps of auditing is considered one of the final auditing procedures that assist the auditor in evaluating the conclusions reached regarding the balance of an account or evaluating the overall presentation of the financial statements. 
The objectives and methods that the auditor seeks to achieve when applying the analytical procedures are similar in the final stage of auditing to those objectives that he seeks to achieve at the planning stage of the auditing process, which helps to draw attention. In other words, the auditor applies the analytical procedures in light of the changes and modifications resulting from the auditing process on account balances so that in case undesirable results are obtained, the auditor is required to investigate the causes of these results. As a final step in the auditing, the auditor should verify whether the enterprise is able to continue its activity for at least one year from the date of the prepared budget under the results obtained from the auditing process. Finally, the auditor obtains a final objective view of the financial statements that he has audited in applying the analytical procedures at the end of the auditing process (Palil et al, 2016). The third sub-hypothesis can be formulated as follows:

$\mathrm{HO}_{2}$ : There is no statistically significant impact of using the analytical procedures during the final stage of the auditing process on reducing the cost of a tax audit in Jordan.

\section{The Study Methodology}

\subsection{Method}

The study was based on the analytical descriptive approach to identify the impact of using the analytical procedures on reducing the cost of a tax audit in Jordan. The books, past literature, instructions, legislation and financial reports related to tax in Jordan were also used. A questionnaire was used in collecting information: this questionnaire consisted of two parts. The first one is about the demographic characteristics of the study sample. The second relates to the independent variables (Auditing stages) and the dependent variable (the cost of tax audit). For the purpose of this questionnaire, the Likert Scale which ranges from 1-5 (5 = strongly agree, $4=$ agree, 3 = neutral, 2 = disagree, $1=$ strongly disagree) was adopted. The degree of using the analytical procedure was determined based on the arithmetic mean as follows (1- 2.33 weak, 2.34- 3.66 middle, 3.67-5.00 high). The stability of the instrument used to measure the variables included in the questionnaire was ascertained by calculating the value of the Cronbach Alpha coefficient, which measures the consistency and harmony of the questionnaire questions.

\subsection{Data Collection}

The study population consisted of the audit directorates in the income and sales tax department operating in Jordan and its number is (12). The study sample was conducted by the auditors of the Directorate of senior taxpayers and medial taxpayers directorates which are (600) auditors who are engaged in the audit work (Income and Sales Tax Department, Annual Report 2015). This type of samples was selected because the Directorate of senior taxpayers is a starting point for any new ideas; any new creative idea is evaluated in the directorate then is applied in other directorates after validity. An appropriate simple random sample which represents the study population was selected in accordance with the random table set by (Sekaran and Bougie, 2016), which refers to the appropriate number for the study sample which should represent the community (234). After determining the sample size, (300) questionnaires were distributed on each of First Trade Directorate, Second Trade Directorate, Service Sector Directorate, Industrial Sector Directorate. (264) questionnaires were retrieved which make up (88\%); (3) questionnaires were excluded because of their insufficiency. The analyzed questionnaires were (261) which make up (87\%) of the distributed questionnaires.

\subsection{Sample Characteristics}

Table 1. refers to the frequencies and percentages of the demographic variables for the study sample.

Table 1. Description demographic variables for the study sample

\begin{tabular}{lccc}
\hline variable & & Frequency & percentage \\
\hline & Bachelor & 202 & $77.4 \%$ \\
Scientific qualification & Master & 43 & $16.5 \%$ \\
& PhD & 12 & $4.6 \%$ \\
& Other & 4 & $1.5 \%$ \\
Total & $\mathbf{2 6 1}$ & $\mathbf{1 0 0 \%}$ \\
\cline { 2 - 4 } years of experience & Less than 5 years & 16 & $6.1 \%$ \\
& $5-10$ years & 63 & $24.1 \%$ \\
& $11-15$ years & 66 & $25.3 \%$ \\
professional certificate & More than 15 years & 116 & $44.4 \%$ \\
& Total & $\mathbf{2 6 1}$ & $3.1 \%$ \\
& JCPA & - & - \\
& CPA & 23 & $8.8 \%$ \\
& AICPA & 8 & $3.1 \%$ \\
\end{tabular}


Scientific qualification: It was noticed that $77.4 \%$ of the study sample have a Bachelor's degree (202 person) followed by $16.5 \%$ with master's degrees (43 person) followed by $4.6 \%$ with $\mathrm{PhD}$ degrees (12 person) while $1.5 \%$ has a diploma degree (4 person) which indicates the suitability of the academic qualifications of the respondents with the nature of their work. It is an indicator of the interest of the Tax Department to appoint those who are holders of academic degrees.

Number of years of experience in auditing: It was noticed that $44.4 \%$ of the study sample have experience of more than 15 years in the field of audit (116 person) followed by $25.3 \%$ whose experience ranges between 11 and 15 years (66 person) followed by $24.1 \%$ whose experience ranges between 5 and 10 years (63 person) while $6.1 \%$ have less than 5 years of experience. This means that the majority of respondents have experience that qualifies them to understand and recognize the questions of the questionnaire, so their answers will be more logical to support the results of the study.

Holding a professional certificate in the audit: it is obvious that $85.1 \%$ of the study sample does not have a professional certificate in the audit (222 person) while $14.9 \%$ of the study sample have professional certificates (39 person). This requires a recommendation to motivate employees in the Tax Department to apply for professional certificates in the field of audit.

\subsection{Reliability Test}

Table 2 shows the Reliability test in order to verify the reliability of the instrument used to measure the variables included in the questionnaire by calculating the value of the Cronbach's Alpha coefficient where the result is statistically acceptable if its value is greater than (0.80) and as the value is closer to (1) - which means (100\%) this indicates a higher reliability degrees of the study instrument (Sekaran, \&Bougie, 2016). Regarding the data given in Table 1, it is found that the total result of Cronbach's Alpha was $94 \%$, so the instrument of this study can be described as reliable and the data obtained through it are suitable for measuring variables and are subjected to a high degree of reliability. The Cronbach's Alpha ratios ranged between $85.95 \%$ and $90.52 \%$ for all dimensions, which are excellent values above the acceptable ratio of $80 \%$.

Table 2. Cronbach's Alpha test

\begin{tabular}{llcc}
\hline Variable & Stage & Cronbach's Alpha & Paragraphs NO. \\
\hline Analytical & Auditing Planning & $90.52 \%$ & 13 \\
Procedures & Implementation & $89.61 \%$ & 10 \\
& The Auditing End & $85.95 \%$ & 10 \\
Cost of Tax Audit & & $88.37 \%$ & 42 \\
Total & & $94 \%$ & $4 \%$ \\
\hline
\end{tabular}

\subsection{Normal Distribution Test}

The normal distribution test of the collected data was performed to ascertain whether the data were under normal distribution or not. Therefore, (One-Sample Kolmogorov-Smirnov Test) was performed as it is used to test the natural distribution of data in case that the number of cases is greater than (50). One of the normal distribution's conditions is that the Significant value of the data is greater than (0.05) and the K-S value is less than (5) for all dimensions. Based on the test the data distribution is normal where Sig has values greater than $5 \%$ for all dimensions and K-S test values are less than (5) for all dimensions.

\section{Results}

The hypotheses of the study will be tested based on the calculation the arithmetic mean and the standard deviation (SD) of the questions related to the independent variables and the dependent variable. Then, a multiple regression test on the main hypothesis will be performed to identify the impact of the analytical procedures on the cost of audit at all stages of the audit together. Following, the impact of the analytical procedures at every stage of the audit by using simple regression will be identified. 


\subsection{The Analytical Procedures at the Planning Stage of the Audit Process}

Table 3. the arithmetic mean and the standard deviation (SD) of using the analytical procedures at the planning stage of the audit process

\begin{tabular}{|c|c|c|c|c|c|}
\hline $\begin{array}{l}\text { Paragraph } \\
\text { NO. }\end{array}$ & Paragraphs & $\begin{array}{l}\text { The } \\
\text { Arithmetic } \\
\text { Mean }\end{array}$ & $\begin{array}{l}\text { The } \\
\text { Standard } \\
\text { Deviation }\end{array}$ & $\begin{array}{l}\text { Application } \\
\text { Degree }\end{array}$ & Order \\
\hline 1 & $\begin{array}{l}\text { Comparison of balances and/or financial ratios } \\
\text { extracted from the financial statements with their } \\
\text { counterparts during the previous years }\end{array}$ & 3.920 & 0.6774 & High & 11 \\
\hline 2 & $\begin{array}{l}\text { Comparison of balances and/or financial ratios } \\
\text { extracted from the financial statements with their } \\
\text { counterparts of forecasts in the estimated budget }\end{array}$ & 4.023 & 0.6902 & High & 5 \\
\hline 3 & $\begin{array}{l}\text { Comparison of balances and/or financial ratios } \\
\text { extracted from the financial statements with their } \\
\text { counterparts of industry ratios }\end{array}$ & 3,981 & 0.7618 & High & 7 \\
\hline 4 & $\begin{array}{l}\text { Comparison of balances and/or financial ratios } \\
\text { extracted from the financial statements with the } \\
\text { economic expectations of the client's activity. }\end{array}$ & 4.015 & 0.7594 & High & 6 \\
\hline 5 & $\begin{array}{l}\text { Comparison of balances and/or financial ratios } \\
\text { extracted from the financial statements with the } \\
\text { auditor's expectations (by virtue of his experience } \\
\text { and information). }\end{array}$ & 4.100 & 0.5864 & High & 2 \\
\hline 6 & $\begin{array}{l}\text { Comparison of balances and/or financial ratios } \\
\text { extracted from the financial statements with } \\
\text { non-financial statements }\end{array}$ & 3.931 & 0.7199 & High & 10 \\
\hline 7 & $\begin{array}{l}\text { The analytical procedures at the planning stage } \\
\text { contribute to reducing the cost of understanding the } \\
\text { nature of the client's work and planning the works of } \\
\text { the audit procedures. }\end{array}$ & 3.912 & 0.7917 & High & 12 \\
\hline 8 & $\begin{array}{l}\text { The analytical procedures at the planning stage } \\
\text { contribute to determining the strength of the internal } \\
\text { control system }\end{array}$ & 3.778 & 0.9222 & High & 13 \\
\hline 9 & $\begin{array}{l}\text { The analytical procedures at the planning stage } \\
\text { contribute to the design of the audit program in terms } \\
\text { of the quality of the detailed audit. }\end{array}$ & 4.245 & 0.7187 & High & 1 \\
\hline 10 & $\begin{array}{l}\text { The analytical procedures at the planning stage } \\
\text { contribute to the detection of errors or fraud. }\end{array}$ & 4.096 & 0.7661 & High & 3 \\
\hline 11 & $\begin{array}{l}\text { The analytical procedures at the planning stage } \\
\text { contribute to the design of the audit program in terms } \\
\text { of the amount of detailed audit procedures. }\end{array}$ & 4.031 & 0.7119 & High & 4 \\
\hline 12 & $\begin{array}{l}\text { The analytical procedures at the planning stage } \\
\text { contribute to the strengthening of the accounting } \\
\text { information system. }\end{array}$ & 3.973 & 0.7463 & High & 8 \\
\hline 13 & $\begin{array}{l}\text { The analytical procedures at the planning stage } \\
\text { contribute to the design of the audit program in terms } \\
\text { of the timing of the detailed audit procedures. }\end{array}$ & 3.946 & 0.6829 & High & 9 \\
\hline \multicolumn{2}{|c|}{ Overall Indicator } & 3.996 & 0.5530 & High & \\
\hline
\end{tabular}

Table (3) shows the arithmetic mean, the standard deviation (SD), and order of respondents' responses to the use of the analytical procedures at the planning stage of the audit process, which were measured based on (13) paragraphs. The results indicate that this stage achieved an arithmetic mean of (3.996) with a ratio of (79.9\%) of the total scale area and with a standard deviation of (0.5530). This indicates that the level of implementation of the planning stage of the audit process was at the highest level from the point of view of the sample population. The results in Table (3) indicate that the highest arithmetic mean was for paragraph (9) where it reached (4.245) with a standard deviation of (0.7187) and with a high level while the lowest the arithmetic mean was for paragraph (8) where it reached (3.778) with a standard deviation of (0.9222). 


\subsection{The Analytical Procedures at the Implementation (Fieldwork) Stage}

Table 4. The arithmetic mean and the standard deviation of using the analytical procedures at the Implementation stage

\begin{tabular}{|c|c|c|c|c|c|}
\hline $\begin{array}{l}\text { Paragraph } \\
\text { No }\end{array}$ & Paragraphs & $\begin{array}{l}\text { The } \\
\text { Arithmetic } \\
\text { Mean }\end{array}$ & $\begin{array}{l}\text { The Standard } \\
\text { Deviation }\end{array}$ & $\begin{array}{l}\text { Application } \\
\text { Degree }\end{array}$ & order \\
\hline 1 & $\begin{array}{l}\text { Comparison of balances and/or financial ratios } \\
\text { extracted from the financial statements with their } \\
\text { counterparts during the previous years. }\end{array}$ & 3.950 & 0.7853 & High & 4 \\
\hline 2 & $\begin{array}{l}\text { Comparison of balances and/or financial ratios } \\
\text { extracted from the financial statements with their } \\
\text { counterparts of forecasts in the estimated budget. }\end{array}$ & 3.747 & 0.9674 & High & 8 \\
\hline 3 & $\begin{array}{l}\text { Comparison of balances and/or financial ratios } \\
\text { extracted from the financial statements with their } \\
\text { counterparts of industry ratios. }\end{array}$ & 3.778 & 0.9346 & High & 6 \\
\hline 4 & $\begin{array}{l}\text { Comparison of balances and/or financial ratios } \\
\text { extracted from the financial statements with the } \\
\text { economic expectations of the client's activity. }\end{array}$ & 3.977 & 0.8130 & High & 3 \\
\hline 5 & $\begin{array}{l}\text { Comparison of balances and/or financial ratios } \\
\text { extracted from the financial statements with the } \\
\text { auditor's expectations (by virtue of his experience } \\
\text { and information). }\end{array}$ & 3.724 & 0.9490 & High & 9 \\
\hline 6 & $\begin{array}{l}\text { Comparison of balances and/or financial ratios } \\
\text { extracted from the financial statements with } \\
\text { non-financial statements. }\end{array}$ & 3.682 & 0.8828 & High & 10 \\
\hline 7 & $\begin{array}{l}\text { The analytical procedures contribute to the } \\
\text { evaluation of the client's financial data and } \\
\text { statements. }\end{array}$ & 3.843 & 0.8739 & High & 5 \\
\hline 8 & $\begin{array}{l}\text { The analytical procedures contribute to determining } \\
\text { differences that might be acceptable that do not } \\
\text { require further examination. }\end{array}$ & 3.751 & 0.8919 & High & 7 \\
\hline 9 & $\begin{array}{l}\text { The analytical procedures contribute to reducing the } \\
\text { detailed tests required for balances and disclosures. }\end{array}$ & 4.080 & 0.7925 & High & 2 \\
\hline 10 & $\begin{array}{l}\text { The analytical procedures contribute to reducing the } \\
\text { size of the audit evidence that must be collected. }\end{array}$ & 4.082 & 0.8211 & High & 1 \\
\hline \multicolumn{2}{|c|}{ Overall Indicator } & 3.861 & 0.6593 & High & \\
\hline
\end{tabular}

Table (4) shows the arithmetic mean, the standard deviation (SD), and order of respondents' responses towards the second independent variable (the analytical procedures at the implementation stage) which were measured using (10) paragraphs. The table indicates that this stage achieved an arithmetic mean of (3.861) with a ratio of (77.2\%) of the total scale area and with a standard deviation of (0.6593). This indicates that the level of implementation of the Implementation stage was at the highest level from the point of view of the sample population. The results in Table (4) indicate that the highest arithmetic mean was for paragraph (10) where it reached (4.082) with a standard deviation of (0.8211) and with a high level while the lowest arithmetic mean was for paragraph (6) where it reached (3.682)with a standard deviation of (0.8828) and with a high level. 


\subsection{The Analytical Procedures at the Final Stage}

Table 5. The arithmetic mean and the standard deviation of the using the analytical procedures at the final stage

\begin{tabular}{|c|c|c|c|c|c|}
\hline $\begin{array}{l}\text { Paragraph } \\
\text { No }\end{array}$ & Paragraphs & $\begin{array}{l}\text { The } \\
\text { Arithmetic } \\
\text { Mean }\end{array}$ & $\begin{array}{l}\text { The } \\
\text { Standard } \\
\text { Deviation }\end{array}$ & $\begin{array}{l}\text { Application } \\
\text { Degree }\end{array}$ & order \\
\hline 1 & $\begin{array}{l}\text { Comparison of balances and/or financial ratios } \\
\text { extracted from the financial statements with their } \\
\text { counterparts during the previous years. }\end{array}$ & 3.885 & 0.9126 & High & 5 \\
\hline 2 & $\begin{array}{l}\text { Comparison of balances and/or financial ratios } \\
\text { extracted from the financial statements with their } \\
\text { counterparts of forecasts in the estimated budget. }\end{array}$ & 3.935 & 0.8985 & High & 4 \\
\hline 3 & $\begin{array}{l}\text { Comparison of balances and/or financial ratios } \\
\text { extracted from the financial statements with their } \\
\text { counterparts of industry ratios. }\end{array}$ & 3.736 & 0.9583 & High & 10 \\
\hline 4 & $\begin{array}{l}\text { Comparison of balances and/or financial ratios } \\
\text { extracted from the financial statements with the } \\
\text { economic expectations of the client's activity. }\end{array}$ & 3.785 & 0.9156 & High & 8 \\
\hline 5 & $\begin{array}{l}\text { Comparison of balances and/or financial ratios } \\
\text { extracted from the financial statements with the } \\
\text { auditor's expectations (by virtue of his experience and } \\
\text { information). }\end{array}$ & 3.950 & 0.8375 & High & 2 \\
\hline 6 & $\begin{array}{l}\text { Comparison of balances and/or financial ratios } \\
\text { extracted from the financial statements with } \\
\text { non-financial statements. }\end{array}$ & 3.969 & 0.8588 & High & 1 \\
\hline 7 & $\begin{array}{l}\text { The analytical procedures contribute to exploring the } \\
\text { possibility of the enterprise's continuation during the } \\
\text { coming years. }\end{array}$ & 3.946 & 0.8754 & High & 3 \\
\hline 8 & $\begin{array}{l}\text { The analytical procedures contribute to exploring the } \\
\text { adequacy of the audit evidence that had been collected } \\
\text { and the audit tests that had been performed. }\end{array}$ & 3.812 & 0.8634 & High & 6 \\
\hline 9 & $\begin{array}{l}\text { The analytical procedures contribute to determining the } \\
\text { extent to which the financial statements are in line with } \\
\text { the auditor's expectations about the business } \\
\text { environment and the nature of the activity after the } \\
\text { auditor completed all the audit works. }\end{array}$ & 3.785 & 0.8987 & High & 7 \\
\hline 10 & $\begin{array}{l}\text { The analytical procedures contribute to revealing the } \\
\text { unexpected numbers and percentages. }\end{array}$ & 3.774 & 0.9399 & High & 9 \\
\hline \multicolumn{2}{|c|}{ Overall Indicator } & 3.858 & 0.6210 & High & \\
\hline
\end{tabular}

Table (5) shows the arithmetic mean, the standard deviation (SD), and order of respondents' responses towards the third independent variable (the analytical procedures at the final stage) which were measured based on (10) paragraphs. The table indicates that this stage achieved an arithmetic mean of (3.858) with a ratio of (77.2\%) of the total scale area and with a standard deviation of (0.621). This indicates that the level of implementation of the final stage was at a high level from the point of view of the sample's individuals. The results in Table (5) indicate that the highest arithmetic mean was for paragraph (6) where it reached (3.969) with a standard deviation of (0.8588) and with a high level while the lowest arithmetic mean was for paragraph (3) where it reached (3.736) with a standard deviation of (0.9583) and with a high level. 


\subsection{The Dependent Variable - the Reducing Cost of Tax Audit}

Table 6 shows the arithmetic mean, the standard deviation (SD), and order of respondents' responses to the cost of a tax audit, which were measured based on (9) paragraphs.

Table 6. The arithmetic mean and the standard deviation of reducing the cost of tax audit.

\begin{tabular}{|c|c|c|c|c|c|}
\hline $\begin{array}{l}\text { Paragraph } \\
\text { No. }\end{array}$ & Paragraphs & $\begin{array}{l}\text { The } \\
\text { Arithmetic } \\
\text { Mean }\end{array}$ & $\begin{array}{l}\text { The } \\
\text { Standard } \\
\text { Deviation }\end{array}$ & $\begin{array}{l}\text { Application } \\
\text { Degree }\end{array}$ & order \\
\hline 1 & $\begin{array}{l}\text { The analytical procedures work on reducing the time } \\
\text { required for the audit process. }\end{array}$ & 3.835 & 0.8319 & High & 7 \\
\hline 2 & $\begin{array}{l}\text { The analytical procedures work on reducing the amount } \\
\text { of effort in the audit process. }\end{array}$ & 3.858 & 0.9683 & High & 6 \\
\hline 3 & $\begin{array}{l}\text { The analytical procedures work on reducing the other } \\
\text { audit tests. }\end{array}$ & 4.073 & 0.9993 & High & 2 \\
\hline 4 & $\begin{array}{l}\text { The analytical procedures work on reducing the cost by } \\
\text { reducing the size of the audit sample. }\end{array}$ & 4.356 & 0.7282 & High & 1 \\
\hline 5 & $\begin{array}{l}\text { The analytical procedures work on reducing the cost by } \\
\text { reducing the cost of the audit process and collecting the } \\
\text { clients' data. }\end{array}$ & 4.061 & 0.8063 & High & 3 \\
\hline 6 & $\begin{array}{l}\text { The analytical procedures work on reducing the cost by } \\
\text { reducing the numbers of employees and testing samples } \\
\text { in the audit process. }\end{array}$ & 3.904 & 0.8651 & High & 5 \\
\hline 7 & $\begin{array}{l}\text { The analytical procedures work on reducing the cost by } \\
\text { reducing the size of the audit sample. }\end{array}$ & 4.046 & 0.8215 & High & 4 \\
\hline 8 & $\begin{array}{l}\text { The analytical procedures work on reducing the cost by } \\
\text { reducing the cost of the audit process and collecting the } \\
\text { clients' data. }\end{array}$ & 3.736 & 0.8338 & High & 9 \\
\hline 9 & $\begin{array}{l}\text { The analytical procedures work on reducing the cost by } \\
\text { reducing the numbers of employees and testing samples } \\
\text { in the audit process. }\end{array}$ & 3.736 & 0.7665 & High & 8 \\
\hline \multicolumn{2}{|c|}{ Overall Indicator } & 3.956 & 0.6393 & High & \\
\hline
\end{tabular}

The table shows that the reducing of the tax audit achieved an arithmetic mean of (3.956) with a ratio of (79.1\%) of the total scale area and with a standard deviation of (0.6393). This indicates that the level of efficiency of the analytical procedures in reducing the cost of tax audit was at a high level from the point of view of the sample population. The results in Table 6 indicate that the highest arithmetic mean was for paragraph (4) where it reached (4.356) with a standard deviation of (0.7282) and with a high level while the lowest arithmetic mean was for paragraph (8) where it reached (3.736)with a standard deviation of (0.8338) and with a high level.

\subsection{Regression analysis}

The main hypothesis: There is no statistically significant impact of using the analytical procedures during all stages of the auditing on reducing the cost of a tax audit in Jordan.

This hypothesis was tested by using the multiple linear regression test and its results were as shown in Table (7).

Table 7. result of multiple linear regression test to Impact Analytical Procedures on Cost of Tax Audit

\begin{tabular}{|c|c|c|c|c|c|c|c|c|c|c|}
\hline \multirow[b]{2}{*}{ dependent } & \multicolumn{2}{|c|}{$\begin{array}{c}\text { Model } \\
\text { Summary }\end{array}$} & \multicolumn{3}{|c|}{ ANOVA } & \multicolumn{5}{|c|}{ Coefficient } \\
\hline & $\mathrm{R}$ & $\mathrm{R}^{2}$ & F-value & Sig & $\mathrm{df}$ & Independent & $\begin{array}{l}\text { Std. } \\
\text { Error }\end{array}$ & B & $t$ value & Sig \\
\hline \multirow{3}{*}{$\begin{array}{l}\text { Cost of tax } \\
\text { audit }\end{array}$} & \multirow{3}{*}{0.883} & \multirow{3}{*}{0.78} & \multirow{3}{*}{303.15} & \multirow{3}{*}{$0.00 *$} & \multirow{3}{*}{$3 / 257$} & \multirow{3}{*}{$\begin{array}{l}\text { Planning stage } \\
\text { implementation } \\
\text { stage } \\
\text { The Auditing End } \\
\text { stage }\end{array}$} & 0.052 & 0.264 & 5.867 & $0.00 *$ \\
\hline & & & & & & & 0.056 & 0.159 & 2.753 & $0.006^{*}$ \\
\hline & & & & & & & 0.054 & 0.536 & 10.242 & $0.00^{*}$ \\
\hline
\end{tabular}

$* P \leq 0.05$

F - Distribution Table $=(2.60)$

$\mathrm{T}$ - Distribution Table $=(1.960)$

Table (7) refers to the existence of a statistically significant impact of applying the analytical procedures on the cost of tax audit through the value of F (303.146) which is larger than its tabular value and is significant at the level of significance of significance of $(\alpha \leq 0.05)$, which also represents the significance of this model at the degree of freedom (257/3). The value of R2 (0.780) indicates that the application of the analytical procedures explained $(78 \%)$ of reducing the cost of the tax audit. The correlation coefficient was $\mathrm{R}=(88.3 \%)$ which indicates a strong relationship between variables.

The results of the partial analysis of this hypothesis show that the final stage had the greatest impact among the 
three analytical procedures on the dependent variable (reducing of the cost tax audit) with a beta coefficient of $(\beta=0.536)$. What enhances this impact is the value of $(t)$ calculated as $(10.242)$ which is greater than its tabular value with a significant level of ( $\mathrm{Sig}=0.00)$. Then it was ranked second in terms of the impact (the planning stage of the audit) with a beta coefficient of $(\beta=0.264)$. What enhances this impact is the value of (T) calculated as (5.867) which is greater than its tabular value with a significant level of $(\mathrm{Sig}=0.00)$. Then, it came in third place in terms of impact (the stage of implementation) with a beta coefficient of $(\beta=0.159)$. What enhances this impact is the value of $\mathrm{T}$ - Statistics as (2.753) which is greater than its $\mathrm{T}$ - Distribution Table with a significant level of $(\mathrm{Sig}=0.006)$.

Based on the above, we reject the null hypothesis and accept the alternative hypothesis where a statistically significant impact was found at the level of significance $(\alpha \leq 0.05)$ to use the analytical procedures (planning, implementation, and final stage) on reducing the cost of a tax audit.

First sub-hypothesis hypothesis: There is no statistically significant impact of using the analytical procedures during the Planning auditing stage on the reducing cost of a tax audit in Jordan

This hypothesis was tested using the simple linear regression test and its results were as shown in Table (8).

Table 8. result of multiple linear regression test to Impact Analytical Procedures in Stage on Cost of Tax Audit

\begin{tabular}{|c|c|c|c|c|c|c|c|}
\hline \multirow[b]{2}{*}{ dependent } & \multicolumn{2}{|c|}{ Model Summary } & \multicolumn{5}{|l|}{ Coefficient } \\
\hline & $\mathrm{R}$ & $\mathrm{R}^{2}$ & Independent & Std. Error & T-Statistics & $\begin{array}{l}\text { T- } \\
\text { Distribution } \\
\text { Table }\end{array}$ & Sig \\
\hline $\begin{array}{l}\text { Cost of tax } \\
\text { audit }\end{array}$ & 0.751 & 0.564 & Planning stage & 0.047 & 18.299 & 1.96 & $0.00 *$ \\
\hline
\end{tabular}

Table (8) refers to the existence of a statistically significant impact of the planning stage of the audit process through the value of $\mathrm{T}(18.299)$ which is a significant value at the level of significance $(\alpha \leq 0.05)$ and greater than its T - Distribution Table of (1.96) which also represents the significance of this model at one point. The value of R2 (0.564) indicates that the planning stage of the audit process explained (56.4\%) of the change in the cost of the tax audit. The correlation coefficient was $\mathrm{R}=(75.1 \%)$ which indicates a strong relationship between the two variables.

Based on the above, we reject the null hypothesis and accept the alternative hypothesis where a statistically significant impact was found at the level of significance at $(\alpha \leq 0.05)$ to apply the analytical procedures at the planning stage on reducing the cost of the tax audit.

Second sub-hypothesis test: There is no statistically significant impact of using the analytical procedures during the implementation auditing stage on the reducing cost of a tax audit in Jordan

This hypothesis was tested using the simple linear regression test and its results were as shown in Table (9).

Table 9. result of multiple linear regression test to Impact Analytical Procedures in Implementation Stage on reducing Cost of Tax Audit

\begin{tabular}{|c|c|c|c|c|c|c|c|}
\hline \multirow[b]{2}{*}{ Dependent } & \multicolumn{2}{|c|}{ Model Summary } & \multicolumn{5}{|c|}{ Coefficient } \\
\hline & $\mathrm{R}$ & $\mathrm{R}^{2}$ & Independent & Std. Error & $\begin{array}{l}\mathrm{T}- \\
\text { Statistics }\end{array}$ & $\begin{array}{l}\text { T- } \\
\text { Distribution } \\
\text { Table }\end{array}$ & Sig \\
\hline $\begin{array}{l}\text { cost of tax } \\
\text { audit }\end{array}$ & 0.798 & 0.636 & $\begin{array}{l}\text { implementation } \\
\text { stage }\end{array}$ & 0.036 & 21.295 & 1.96 & $0.00 *$ \\
\hline
\end{tabular}

$* P<0.05$

Table (9) refers to the existence of a statistically significant impact of the implementation stage through the value of $\mathrm{T}(21.295)$ which is a significant value at the level of significance $(\alpha \leq 0.05)$ and greater than its Distribution Table (1.96) which also represents the significance of this model at one point. The value of R2 (0.636) indicates that the fieldwork stage explained (63.6\%) of the change in the cost of the tax audit. The correlation coefficient was $\mathrm{R}=(79.8 \%)$ which indicates a strong relationship between the two variables.

Based on the above, we reject the null hypothesis and accept the alternative hypothesis where a statistically significant impact was found at the level of significance of $(\alpha \leq 0.05)$ to use the analytical procedures at the Implementation on reducing the cost of the tax audit.

Third sub-hypothesis test results: There is no statistically significant impact of using the analytical procedures during the final auditing stage on the reducing cost of a tax audit in Jordan

This hypothesis was tested using the simple linear regression test and its results were as shown in Table (10). 
Table 10. result of multiple linear regression test to Impact Analytical Procedures in reducing The Auditing End stage on Cost of Tax Audit

\begin{tabular}{|c|c|c|c|c|c|c|c|}
\hline \multirow[b]{2}{*}{ dependent } & \multicolumn{2}{|c|}{ Model Summary } & \multicolumn{5}{|c|}{ Coefficient } \\
\hline & $\mathrm{R}$ & $\mathrm{R}^{2}$ & Independent & $\begin{array}{l}\text { Std. } \\
\text { Error }\end{array}$ & T-Statistics & $\begin{array}{l}\text { T- } \\
\text { Distribution } \\
\text { Table }\end{array}$ & Sig \\
\hline $\begin{array}{l}\text { cost of tax } \\
\text { audit }\end{array}$ & 0.848 & 0.719 & $\begin{array}{l}\text { The Auditing } \\
\text { End stage }\end{array}$ & 0.034 & 25.746 & 1.96 & $0.00 *$ \\
\hline
\end{tabular}

Table (10) refers to the existence of a statistically significant impact of the final stage through the value of $T$ $(25,746)$ which is a significant value at the level of significance $(\alpha \leq 0.05)$ and greater than its $T$ - Distribution Table of (1.96) which also represents the significance of this model at one point. The value of R2 (0.719) indicates that the final stage explained (71.9\%) of the change in the cost of the tax audit. The correlation coefficient was $\mathrm{R}=(84.8 \%)$ which indicates a strong relationship between the two variables.

Based on the above, we reject the null hypothesis and accept the alternative hypothesis where a statistically significant impact was found at the level of significance $(\alpha \leq 0.05)$ to use the analytical procedures at the final stage at reducing the cost of the tax audit.

\section{Conclusions}

The tax auditor in the audit process relies mainly on the analytical procedures to achieve his work at all stages of the tax audit with the least time, effort and cost. Because of that, the study aimed at identifying the impact of using the analytical procedures in reducing the tax audit cost in the three different stages of the audit (planning, field implementation, final stage). Using the analytical procedures increases the efficiency of the tax audit process by contributing to the reduction of some of the necessary tests which reduce the size, time and cost in collecting the audit evidence which increases the efficiency of an audit, especially at the end of the audit. Followed by the planning stage and finally the stage of Implementation that indicates the importance of the analytical procedures for the auditors in the final stage of the audit process; for being the stage that the audit cost can be reduced in it. The auditor's experience in using the analytical procedures plays a major role in determining the relationships and variables about the data provided by the owner of the enterprise and thus avoiding any fraud or manipulation, which enhances the efficiency of the tax audit process in preventing waste or assaulting public money. The income and sales tax auditors in Jordan have the adequate skills and experience about using the analytical procedures, which facilitate their mission and help in reducing the cost of a tax audit.

\section{Recommendations}

Based on the above, because analytical procedures help to save the cost of tax audit, must encourage auditor to using the analytical procedures during the process of tax audit and the enactment of laws and regulations that obligate auditors in the Income and Sales Tax Department to use them at all stages of audit in order to raise the efficiency and effectiveness of work with the lowest costs. In addition, holding professional symposiums and workshops in the field of the analytical procedures to inform the auditors with its importance in raising the efficiency of work. Also, improving the interaction between professional accounting organizations and related associations to develop and improve the audit profession and to update the standards and methods of the audit profession to cope with recent developments and professional requirements in the field. Finally, using the analytical procedures will lead to increase the efficiency and effectiveness of the audit profession and support researches and studies that are looking at the development of the audit profession that overall will develop the profession of the tax audit.

\section{References}

Ahmad, N., Mohammed, Z. M., Iskandar, T. M., Hanefah, H. M. M., \&Faizal, S. M. (2014). Outsourcing Malaysia federal tax audit: The stakeholders' views. Journal Pengurusan (UKM Journal of Management), 41. https://doi.org/10.17576/pengurusan-2014-41-02

Al-Sharairi, J. (2011). The Reality and Constraints of Using Analytical Procedures in the Control of Public Fund Jordanian Audit Bureau Case. European Journal of Economics, Finance \& Administrative Sciences, 34(7).

Arens, A. A., \& Elder, R. J. dan Mark S. Beasley. (2015). Auditing and Assurance Services: An Integrated Approach.

Bednarek, P. (2016). Evaluating The Usefulness Of Quantitative Methods As Analytical Auditing Procedures. Research Papers of the Wroclaw University of Economics/ PraceNaukoweUniwersytetuEkonomicznego we Wroclawiu, (434). 
Dittenhofer, M. (2001). Analytical auditing and risk analysis in government. Managerial Auditing Journal, 16(8), 469-476. https://doi.org/10.1108/02686900110403172

Gendron, Y., Cooper, D. J., \& Townley, B. (2007). The construction of auditing expertise in measuring government performance. Accounting, organizations and society, 32(1-2), 101-129. https://doi.org/10.1016/j.aos.2006.03.005

Glover, S. M., Prawitt, D. F., \& Drake, M. S. (2014). Between a rock and a hard place: A path forward for using substantive analytical procedures in auditing large P\&L accounts: Commentary and analysis. Auditing: A Journal of Practice \& Theory, 34(3), 161-179. https://doi.org/10.2308/ajpt-50978

Income and Sales Tax Guide, (2015). "Audit Guide" Income and Sales Tax Department, Jordan

International Federation of Accountants (IFAC). (2011). International Auditing and Assurance Standards Board-Exposure Drafts.www.IFAC.org

International Standards on Auditing, https://www.iaasb.org/clarity-center/clarified-standards

Knapp, C. A., \& Knapp, M. C. (2001). The effects of experience and explicit fraud risk assessment in detecting fraud with analytical procedures. Accounting, Organizations and Society, 26(1), 25-37. https://doi.org/10.1016/S0361-3682(00)00005-2

Knechel, W. R., \&Salterio, S. E. (2016). Auditing Assurance and risk. Routledge. https://doi.org/10.4324/9781315531731

Lushi, I. (2016). Effect of integrity of the officers on reduce the tax evasion or increase of the revenue-Survey in Kosovo. European Journal of Sustainable Development, 5(2), 51-56.

Messier Jr, W. F., Simon, C. A., \& Smith, J. L. (2013). Two decades of behavioral research on analytical procedures: What have we learned? Auditing: A Journal of Practice \& Theory,32(1), 139-181. https://doi.org/10.2308/ajpt-50327

Messier, W. F., Glover, S. M., \& Prawitt, D. F. (2012). Auditing \& assurance services: A systematic approach. Boston, MA: McGraw-Hill Irwin.

Montgomery, D. D., Beasley, M. S., Menelaides, S. L., \&Palmrose, Z. V. (2002). Auditors' new procedures for detecting fraud. Journal of Accountancy, 193(5), 63.

Mumford, A. (2017). Taxing culture: towards a theory of tax collection law. Routledg. https://doi.org/10.4324/9781315241753

Murphy, K. E., \& Higgins, M. (2016). Concepts in Federal Taxation 2017. Cengage Learning.

Olaoye, C. O., \&Ogundipe, A. A. (2018). Application of Tax Audit and Investigation on Tax Evasion Control in Nigeria. Journal of Accounting, Finance and Auditing Studies, 4(1), 79-92.

Oyedokun, G. (2016). Imperatives of Tax Audit and Investigation for Revenue Generation in Nigeria.

Palil, M. R. (2016). Issues, challenges and problems with tax evasion: The institutional factors approach. GadjahMada International Journal of Business, 18(2), 187. https://doi.org/10.22146/gamaijb.12573

Pinho, C. (2014). The usefulness of analytical procedures: an empirical approach in the auditing sector in Portugal.

Rittenberg, L. E., Johnstone, K. M., \&Gramling, A. A. (2010). Auditing: A business risk approach.

Sekaran, U., \& Bougie, R. (2016). Research methods for business: A skill building approach. John Wiley \& Sons.

Solayman, S. H. (2017). The Impact of Using Analytical Auditing in Reducing Cost and Increasing Effectiveness of External Auditing (Unpublished Master's Thesis). Al-NeelainUniversity. Khartoum, Sudan.

Soltani, B. (2007). Auditing: An international approach. pearson education

Tandon, B. N. (2007). Handbook of Practical Auditing. S. Chand.

The U.S. Government Accountability Office (GAO) https://www.gao.gov/img_library/about/US-GAO-logo.png

\section{Copyrights}

Copyright for this article is retained by the author(s), with first publication rights granted to the journal.

This is an open-access article distributed under the terms and conditions of the Creative Commons Attribution license (http://creativecommons.org/licenses/by/4.0/). 